\title{
Perivascular Fat and the Microcirculation: Relevance to Insulin Resistance, Diabetes, and Cardiovascular Disease
}

\author{
A. J. Houben • E. C. Eringa • A. M. Jonk • E. H. Serne • \\ Y. M. Smulders • C. D. Stehouwer \\ Published online: 22 November 2011 \\ (C) The Author(s) 2011. This article is published with open access at Springerlink.com
}

\begin{abstract}
Type 2 diabetes and its major risk factor, obesity, are a growing burden for public health. The mechanisms that connect obesity and its related disorders, such as insulin resistance, type 2 diabetes, and hypertension, are still undefined. Microvascular dysfunction may be a pathophysiologic link between insulin resistance and hypertension in obesity. Many studies have shown that adipose tissue-derived substances (adipokines) interact with (micro)vascular function and influence insulin sensitivity. In the past, research focused on adipokines from perivascular adipose tissue (PVAT). In this review, we focus on the interactions between adipokines, predominantly from PVAT, and microvascular function in relation to the development of insulin resistance, diabetes, and cardiovascular disease.
\end{abstract}

Keywords Microvascular dysfunction · Perivascular adipose tissue $\cdot$ Insulin resistance $\cdot$ Diabetes $\cdot$ Obesity Hypertension

A. J. Houben · A. M. Jonk · C. D. Stehouwer

Department of Internal Medicine, Maastricht University Medical Center and Cardiovascular Research Institute Maastricht,

Maastricht, the Netherlands

E. C. Eringa

Department of Physiology, VU University medical center and Institute for Cardiovascular Research

VU university medical center,

Amsterdam, The Netherlands

E. H. Serne $\cdot$ Y. M. Smulders

Department of Internal Medicine, VU University medical center and Institute for Cardiovascular Research VU university medical center, Amsterdam, The Netherlands

\section{A. J. Houben $(\bowtie)$}

Department of Internal Medicine,

Maastricht University Medical Center,

PO Box 5800, 6202 AZ Maastricht, the Netherlands

e-mail: b.houben@maastrichtuniversity.nl

\section{Introduction}

Type 2 diabetes is a growing worldwide problem. One of the major risk factors for type 2 diabetes mellitus and cardiovascular disease is obesity $[1,2]$. Because the incidence of obesity is increasing worldwide and has reached epidemic proportions in several countries [3], the prevalence of obesity-related disorders, such as insulin resistance and hypertension, is rapidly increasing as well. It has been demonstrated that microvascular dysfunction affects both insulin-mediated glucose disposal [4-7] and peripheral vascular resistance $[8,9]$, contributing to insulin resistance and hypertension, respectively. We and others have shown that microvascular function is impaired in obesity $[6,10,11$, 12•]. Various bioactive compounds produced and released by adipose tissue (adipokines) influence vascular function and insulin sensitivity. In particular, signals from perivascular adipose tissue have been suggested to influence microvascular function contributing to obesity-associated insulin resistance and hypertension. In this review, we focus on the interactions between adipokines and microvascular function in relation to the development of insulin resistance, diabetes, and CVD.

\section{Microcirculation and Perivascular Fat: Definition, Structure, and Function}

\section{Microcirculation}

The microcirculation, including arterioles, capillaries, and venules, can be defined on the basis of vessel diameter $(<$ $150 \mu \mathrm{m}$ ) or on the basis of the physiologic vasoconstrictor response to increased internal pressure [13]. The most important functions of the microcirculation are 1) to regulate tissue perfusion and exchange surface area to ensure adequate delivery of nutrients, oxygen, and hormones; 2) to avoid large fluctuations in hydrostatic pressure at the 
capillary level; and 3) to regulate peripheral vascular resistance and thereby blood pressure [13]. Optimal microvascular function is, therefore, essential for the regulation of whole body and tissue metabolism as well as blood pressure. Various autoregulatory mechanisms (systemic, regional, metabolic, and myogenic) determine microvascular function $[14,15]$. In particular, endothelial cells (forming the inner lining of the microvasculature) play a central role in translating circulating factors (eg, hormones, fatty acids, nutrients) to vasodilator (nitric oxide [NO], endotheliumderived hyperpolarization factor [EDHF], prostaglandins [PGI2/PGE2]) and vasoconstrictor (eg, endothelin-1 [ET-1]) factors [16].

\section{Perivascular Adipose Tissue}

Perivascular fat, or perivascular adipose tissue (PVAT), consists of adipocytes, fibroblasts, stem cells, mast cells, and nerves [17-19]. It can be found throughout the body, around most arteries and veins with a diameter $>50 \mu \mathrm{m}$. Specific locations where PVAT has been studied are around the coronary arteries (epicardial adipose tissue), the aorta (periaortic adipose tissue), and in the microcirculation of the mesentery and adipose tissue [20, 21, 22, 23, 24, 25••]. In muscle, regulation of local perfusion by perivascular adipose tissue has been proposed [23]. Aortic perivascular adipose tissue expands in situations of nutrient excess and obesity [26]. In the heart, PVAT volume has been found to correlate with the amount of intra-abdominal fat [26, 27••]. The mechanisms causing expansion of perivascular adipose tissue are still under investigation, but likely involve differentiation of resident mesenchymal stem cells and preadipocytes, as well as infiltration and differentiation of stem cells from bone marrow. PVAT, at different locations, has been shown to secrete a wide variety of adipose tissuederived hormones (adipokines) and other substances, including hormones, cytokines, chemokines, fatty acids, components of the renin-angiotensin system and oxygen radicals $[20,28]$. However, the rate of excretion of various adipokines may vary between PVAT at different sites in the vascular tree and between PVAT and other adipose tissue depots $[25 \bullet \bullet, 29 \bullet \bullet]$. Adipokines such as fatty acids, tumour necrosis factor $\alpha,(\mathrm{TNF} \alpha)$ and adiponectin have been shown to affect insulin sensitivity and also inflammatory responses, appetite, atherosclerosis, and hemostasis [30].

\section{Microvascular Dysfunction in Insulin Resistance, Obesity, and Hypertension}

Microvascular dysfunction is not only characteristic for insulin resistance and hypertension [31], but may be involved in the pathogenesis and progression of these conditions as well, as microvascular changes have been demonstrated to occur very early, even before clinical manifestation [9, 32-34]. Alternatively, by affecting both peripheral resistance and glucose metabolism, microvascular changes that result from hypertension could also predispose to insulin resistance and vice versa.

\section{Insulin Resistance}

The classic definition of insulin resistance is a decreased sensitivity and/or responsiveness to metabolic actions of insulin that promote glucose disposal. A major action of insulin in skeletal muscle is translocation of the glucose transporter (GLUT-4) to the plasma membrane and subsequent activation of downstream pathways of glucose metabolism [35]. A necessary requirement for this process is delivery of insulin and glucose to tissue interstitium. This delivery is regulated to a great extent by insulin itself via direct effects on vascular function [35, 36•].

Over 20 years ago, several studies demonstrated direct vasodilator effects of insulin in skeletal muscle-resistance vessels, thereby increasing muscle blood flow [4, 37-39]. Subsequently, in a wide range of insulin-resistant states (eg, hypertension, obesity, type 2 diabetes), this vasodilator effect of insulin was shown to be impaired. This led to the hypothesis that the vasodilator and metabolic actions of insulin are functionally coupled $[35,40]$, although the time kinetics and dosages of insulin required to increase total muscle blood flow appear to be different from those for insulin-induced glucose uptake [41, 42]. This apparent dissociation in the effects of insulin on muscle blood flow and glucose uptake resulted in a shift of focus from insulin's actions in the macrocirculation to actions in the microcirculation. The groups of Clark and Barrett then introduced the concept that distribution of blood flow within the microcirculation, independent of changes in total muscle flow, may be important for insulin-mediated glucose metabolism [4, 43, 44]. They showed that insulininduced changes in muscle microvascular perfusion were consistent with capillary recruitment [42, 45-47]. By vasodilation of precapillary arterioles connected to nutritive capillary networks, insulin induces capillary recruitment, resulting in a redistribution of blood flow from putatively non-nutritive transit and/or connective tissue microvessels to nutritive capillaries [40, 48, 49]. This capillary recruitment was shown to be associated with changes in muscle glucose uptake independently of changes in total blood flow, to require lower insulin concentrations than necessary for changes in total blood flow, and to approximate the time course for insulin-mediated glucose uptake in skeletal muscle (ie, 5-10 min) [42, 50, 51]. Approximately 40\% 
of insulin-stimulated muscle glucose uptake can be attributed to this capillary recruitment $[47,51,52]$.

These vasodilator actions of insulin involve the endothelial insulin receptor, insulin receptor substrate 1 and 2 (IRS1 and IRS2), PI3-kinase, phosphoinositide-dependent kinase 1 (PDK-1), and protein kinase B (Akt) [35, 36•]. Insulin-induced stimulation of Akt directly increases endothelial nitric oxide (NO) production via endothelial nitric oxide synthase (eNOS) [35, 53]. The metabolic action of insulin to stimulate glucose uptake in skeletal muscle and adipose tissue is mediated through stimulation of similar PI3-kinase-dependent signaling pathways. Besides vasodilator actions, insulin has vasoconstrictor effects as well. These vasoconstrictor effects are mainly mediated by the vasoconstrictor peptide endothelin-1 (ET1) [35]. ET-1 is produced in the vascular endothelium through stimulation of the intracellular mitogen-active protein kinase (MAPK) signaling pathway and the extracellular signal-regulated kinase-1/2 (ERK1/2) [54]. Thus, insulin has opposing endothelium-derived vasodilator and vasoconstrictor effects, with the net effect being dependent on the balance between these two [12•]. Normally, the net result is vasodilation.

\section{Microcirculation in Obesity and Insulin Resistance}

Most studies examining microvascular function in the insulin-resistant state have been performed in obese individuals [55]. These studies have demonstrated that obese insulin-resistant individuals are characterized by several impairments in the microvasculature. The presence of endothelial dysfunction has been established by blunted NO-mediated vasodilator responses in skin and resistance arterioles to classic endothelium-dependent vasodilators $[11,56-61]$ and impaired capillary recruitment to reactive hyperemia [11, 62]. In support of a causal role for obesity in the pathogenesis of endothelial dysfunction, weight loss has been found to improve endothelial function [63]. At the same time, obese insulin-resistant patients have elevated plasma ET-1 levels [64]. A key feature of insulin resistance is that it is characterized by specific impairment in PI3Kdependent signaling pathways, whereas insulin's signaling through the MAPK pathways remains intact [36•, 65-67], resulting in vasoconstriction. Indeed, several studies have demonstrated impaired vasodilation and capillary recruitment in response to insulin in skin and skeletal muscle of insulin-resistant individuals $[11,68,69,70 \cdot 71,72]$. As metabolic insulin resistance is usually accompanied by compensatory hyperinsulinemia (to maintain euglycemia), this hyperinsulinemia in the vasculature will stimulate unaffected MAPK-dependent pathways, leading to decreased production of NO and increased secretion of ET-1 [54, 66,
73-75]. As a consequence, vasoconstriction of resistance arteries and terminal arterioles occurs, leading to impaired regulation of muscle perfusion, glucose uptake, and blood pressure [13]. Recently, resistance to insulin's effects on vascular endothelium has indeed been shown to control insulin sensitivity in mice [36•].

\section{Microcirculation in Hypertension}

Hypertension per se is also characterized by functional as well as structural changes in the microcirculation [31], including impaired vasoregulation [76], increases in wallto-lumen ratio of small arteries $[31,77]$, and structural and functional capillary rarefaction $[5,13,78,79]$. The presence of endothelial dysfunction in hypertension has been established by blunted vasodilator responses and capillary recruitment to classic endothelium-dependent vasodilators (eg, acetylcholine) and mechanical stimulation (shear stress) [5, 80]. Recent studies also demonstrated impaired insulin-mediated NO-dependent vasodilation in different animal models of hypertension [81-83]. In addition to the decrease in NO availability, hypertension is characterized by a parallel increase in the release of the endothelium-derived contracting factor ET-1 and in the vasoconstrictor angiotensin II (Ang II) [76, 84].

Whereas it has been known for many years that these microvascular alterations can be secondary to sustained elevation of blood pressure $[85,86]$, there is also evidence that microvascular changes can be a cause rather than a consequence of hypertension [8, 9, 87]. Microvascular abnormalities occur early during development of hypertension in spontaneously hypertensive rats (SHR) [81, 88], and prevention of oxidative stress by antioxidant treatment not only prevents rarefaction [88] but also prevents the agerelated development of hypertension [89]. Furthermore, capillary rarefaction, similar to the magnitude seen in patients with established hypertension, can already be demonstrated in individuals with borderline hypertension [8] and in individuals with a familial predisposition to hypertension, even if they themselves are normotensive [9, 32]. Thus, it seems likely that microvascular abnormalities can both result from and contribute to hypertension, and a continuing cycle may exist in which the microcirculation maintains or even amplifies an initial increase in blood pressure. However, microvascular dysfunction (including vascular insulin resistance) due to hypertension may also directly reduce the access of insulin and glucose to skeletal muscle, resulting in reduced insulin sensitivity.

To summarize, there are several arguments for a causal role of microvascular insulin resistance and dysfunction in metabolic insulin resistance and hypertension (Fig. 1) [90]. Subsequently, the hyperglycemia and hyperinsulinemia that 
Fig. 1 The postulated pathophysiologic framework underlying the hypothesis that microvascular dysfunction links hypertension and insulin resistance. ACE-angiotensinconverting enzyme; ARBangiotensin II receptor blocker; RAS - renin-angiotensin system; TNF $\alpha$ - tumor necrosis factor $\alpha$. (Adapted from Jonk [90].)

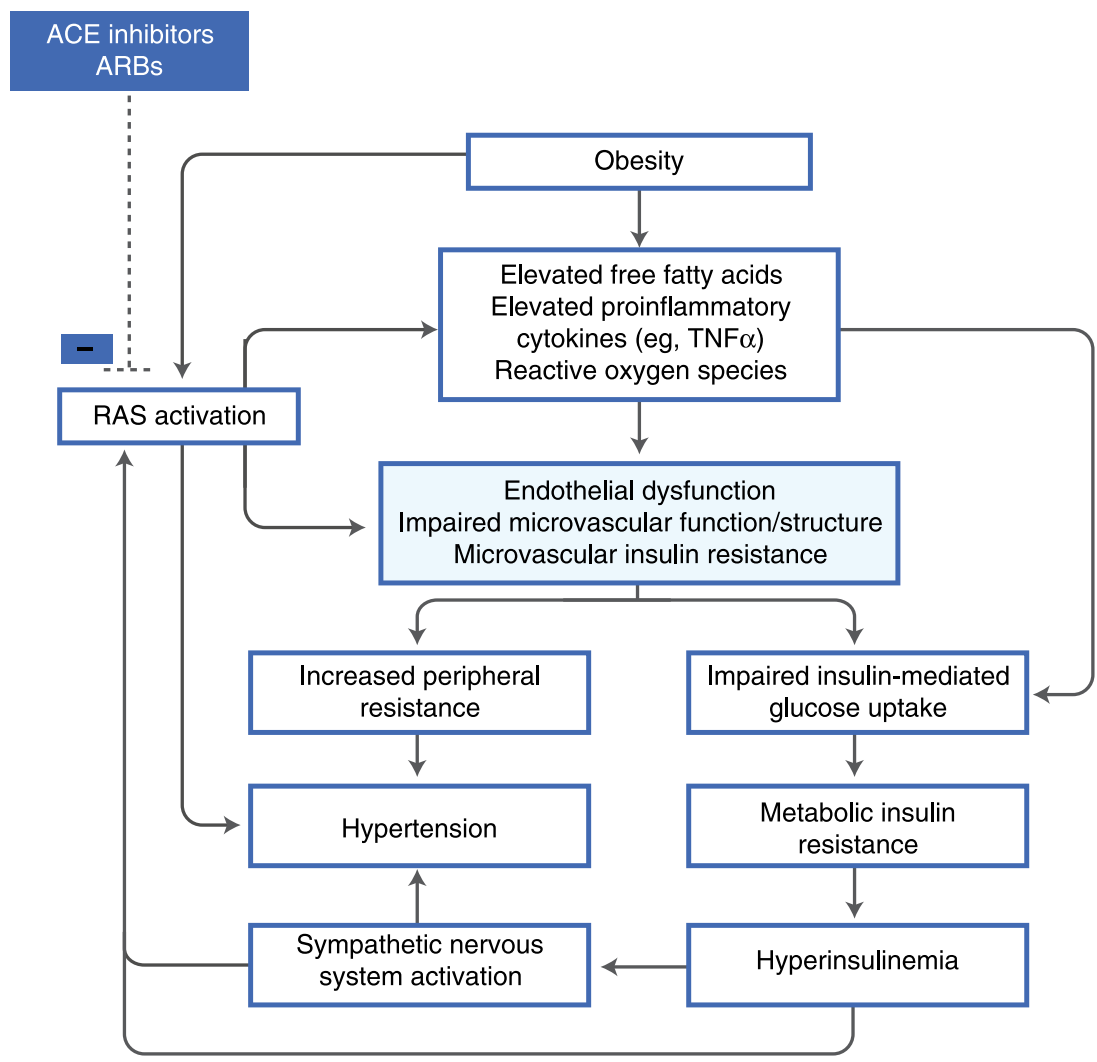

evolve with metabolic insulin resistance can further impair endothelial function [91, 92] and consequently glucose disposal and blood pressure. Hence, it is possible to envision a vicious circle of progressive microvascular dysfunction that contributes to and is exacerbated by worsening metabolic insulin resistance and hypertension.

\section{Adipose Tissue and Microvascular Dysfunction}

The fact that there are associations between measures of adiposity and microvascular function [93] indicates the existence of signaling pathways between adipose tissue and the microcirculation. A large number of recent studies have proven that adipose tissue functions as a highly active endocrine organ. Adipose tissues secrete a variety of bioactive substances called adipokines. In obesity, it has been shown that there is an enhanced production of several adipokines (eg, free fatty acids [FFA], angiotensinogen, leptin, resistin, and several inflammatory cytokines) [63, 94-97], whereas the production of adiponectin, an antiinflammatory adipokine, is reduced [98]. In recent years, perivascular adipose tissue has been identified as a source of adipokines, which are summarized in Table 1 and Fig. 2. The rate of excretion of various adipokines differs between perivascular adipose tissue and other adipose tissue depots, and may vary between PVAT at different sites in the vascular tree $[25 \bullet \bullet, 29 \bullet \bullet]$. Here we discuss some major adipokines and their effects on (micro)vascular function.

\section{Adiponectin}

Adiponectin is an abundant protein in the human circulation that has been shown to be inversely associated with risk for type 2 diabetes, to increase insulin sensitivity, and to improve vascular function $[99,100]$. Adiponectin expression is limited to adipocytes, but paradoxically, its levels are decreased in obesity. This defect has been proposed to be caused by TNF $\alpha$ and interleukin-6 (IL-6), as well as other inflammatory mediators [30,101]. Adiponectin itself can reduce production of proinflammatory cytokines, and favorably affects insulinsignaling pathways [102].

It has been shown that PVAT in the coronary circulation [103] and in adipose tissue produces adiponectin [25••]. In subjects with coronary artery disease, production of adiponectin is reduced in epicardial adipose tissue [104]. In mice, a high-fat diet was found to decrease adiponectin secretion from PVAT [29••]. The secretion of adiponectin by differentiated coronary perivascular adipocytes was much lower when compared to subcutaneous and perirenal adipocytes, suggesting that PVAT would have a more inflammatory profile than other fat depots [29••]. Conversely, another 
Table 1 Products of perivascular adipose tissue involved in regulation of vascular function

\begin{tabular}{ll}
\hline & References \\
\hline Cytokines & \\
TNF $\alpha$ & {$[20,27 \cdot \bullet]$} \\
IL-1 $\beta$ & {$[20,27,27 \cdot \bullet]$} \\
IL-6 & {$[7,19,20]$} \\
Chemokines & \\
MCP-1 & {$[20,111]$} \\
IL-8 & {$[111]$} \\
MIP-1 $\alpha$ & {$[29 \bullet \bullet]$} \\
Hormones and fatty acids & \\
Leptin & {$[29 \cdot \bullet, 110]$} \\
Adiponectin & {$[25 \cdot, 29 \bullet \bullet],[103-105]$} \\
FABP4 & {$[29 \cdot \bullet]$} \\
FFA & {$[110]$} \\
Vasoactive agents & \\
Angiotensinogen & {$[116]$} \\
Ang II & {$[116,130]$} \\
Ang $(1-7)$ & {$[115]$} \\
ROS & {$[110,113,121,125]$} \\
$\mathrm{H}_{2} \mathrm{~S}$ & {$[128]$} \\
\hline A & \\
\hline
\end{tabular}

Ang II angiotensin II; Ang (1-7) angiotensin (1-7); FABP4 fatty acidbinding protein $4 ; \mathrm{H}_{2} \mathrm{~S}$ hydrogen sulphate; FFA free fatty acids; IL interleukin-; MCP-1 monocyte chemoattractant protein-1; MIP-1 $\alpha$ macrophage inflammatory protein- $1 \alpha$; ROS reactive oxygen species; $\mathrm{TNF} \alpha$ tumor necrosis factor $\alpha$

study has reported similar concentrations of adiponectin in PVAT, and subcutaneous and abdominal visceral adipose tissue [105]. However, in the latter study, adiponectin was measured in homogenates of the adipose depots, and synthesis does not necessarily equal secretion.

Leptin

Leptin, the product of the ob gene discovered in 1994, is one of the best-known adipokines. Deficiency of leptin activity leads to severe obesity, insulin resistance, and vascular dysfunction in mice and rats [7, 106], showing that leptin controls metabolism and vascular function. Leptin has been shown to increase NO production in the presence of insulin [107]. In humans, leptin deficiency is associated with hyperphagia, obesity, and insulin resistance [108], although circulating levels of leptin are generally increased in obesity. Recent data have suggested that obesity is a leptin resistant state [109]. Perivascular adipose tissue expresses leptin, although to a somewhat lower extent than subcutaneous and perirenal adipose tissue, and leptin secretion increases during diet-induced obesity $[29 \bullet \bullet, 110]$.
Cytokines and Chemokines

A substantial number of studies have shown that PVAT is a source of predominantly proinflammatory, cytokines and chemokines [20,111, 112]. Mazurek et al. found that epicardial PVAT from 42 patients who underwent elective coronary artery bypass graft $(\mathrm{CABG})$ surgery excreted higher amounts of IL- $1 \beta$, IL-6, IL-6sR, and TNF $\alpha$ than subcutaneous adipose tissue from these same patients [20]. In another study, IL-6 and IL-8 excretion in differentiated perivascular adipocytes was higher than in subcutaneous and perirenal fat, as well as MCP-1 release [29••]. Importantly, the amount of cytokines excreted by PVAT did not correlate with plasma cytokine concentrations. These findings illustrate the importance of adipose tissue location and that systemic concentrations of adipokines may not be representative of local concentrations in tissues. Also, the inflammatory properties of epicardial adipose tissue were independent of obesity [20]. Aside from cytokines, PVAT is also a source of chemokines such as IL-8, MCP-1, and RANTES [111, 113]. These have been implicated in the initiation of vessel wall inflammation and concomitant production of cytokines.

\section{Adventitia-Derived Relaxing Factor}

Perivascular adipose tissue around the aorta and mesenteric arteries of rats has been shown to exert a direct relaxing effect on vascular smooth muscle, mediated by one or more adventitia-derived relaxing factors (ADRFs) $[22,114]$. One of these ADRFs has been identified in rats as angiotensin 1-7 [115]. In humans, adiponectin is a prominent ADRF, and the role of angiotensin 1-7 has not been proven.

\section{Renin-Angiotensin System}

Perivascular adipose tissue has been shown to express all components of the renin-angiotensin system except renin [116], and this has been implicated in the pathogenesis of hypertension. The production of angiotensin II by mesenteric adipose tissue was found to be higher than that in periaortic adipose tissue, showing regional differences in this system [116]. Interestingly, angiotensin II type-1 (AT1) receptor blockade (ARB) improves insulin sensitivity, which seems to be related to effects on adipose tissue [117, 118]. Although acute angiotensin II infusion in healthy subjects reduces capillary density and acute ARB treatment in hypertensive subjects stimulates capillary density, these acute changes in capillary densities are not directly coupled to subsequent changes in insulin-mediated glucose uptake $[119,120]$. 


\section{Reactive Oxygen Species}

Production of reactive oxygen species by PVAT has primarily been found in the larger arteries of rats and mice. ROS production in PVAT is produced by NADPH oxidase in immune cells [113, 121], can be increased by angiotensin II [122], and has been found to be increased in experimental obesity [121].

\section{Perivascular Adipose Tissue as a Regulator of Microvascular Function}

Accumulating evidence suggests that the products of PVAT contribute to regulation of (micro)vascular function and, subsequently as a consequence, may influence organ function and even insulin sensitivity [23, 40]. The hypothesis that perivascular adipose tissue controls glucose metabolism is supported by strong statistical relationships between ectopic fat and insulin sensitivity, the fact that vascular function contributes to regulation of insulin sensitivity [36 $6^{\bullet}$, and by recent evidence that PVAT controls vascular tone $[25 \cdot 0]$. At present, the role of PVAT in the pathogenesis of diabetes and the associated cardiovascular disease is still being defined.

\section{PVAT and Endothelium-Dependent Vasodilation}

Endothelium is an important modifier of vascular tone, and recent evidence suggests PVAT alters the balance between endothelium-dependent vasodilator and vasoconstrictor substances such as NO and endothelin-1 [123]. This is illustrated by studies showing that the amount of PVAT surrounding the brachial artery is negatively associated with post-ischemic increases in forearm blood flow. In contrast, increased PVAT around the brachial artery does not associate with flowmediated dilatation of the brachial artery itself [27••], suggesting that PVAT is able to affect microvascular function at distal sites ("vasocrine" signaling) and that the effects of PVAT are vessel specific. Anti-contractile properties of PVAT are not only seen in large arteries but also in the microcirculation of the mesentery and adipose tissue [25••].

In subcutaneous gluteal fat of healthy lean subjects, anticontractile properties of PVAT around microvessels have also been demonstrated $[25 \cdot \bullet]$. The anti-contractile properties of PVAT were shown to be mediated by adiponectin and were abrogated in patients with metabolic syndrome, suggesting functional differences between PVAT from lean subjects and subjects with metabolic syndrome. Moreover, hypoxia, which is known to decrease adiponectin production, attenuates the anti-contractile properties of PVAT [25••, 124].

PVAT has also been shown to attenuate endotheliumdependent vasodilatation in pathologic situations, and this effect may be mediated by leptin and reactive oxygen species. Epicardial PVAT from swine with a diet-induced metabolic syndrome excretes more leptin than epicardial perivascular adipose tissue in lean swine, and the increased production of leptin attenuates endothelium-dependent vasodilation by activating protein kinase $C$ [110]. In New Zealand obese mice with metabolic syndrome, a role for PVAT-derived reactive oxygen species in attenuation of endotheliumdependent vasodilatation has been demonstrated [121].

Healthy PVAT enhances endothelium-dependent vasodilation, probably through adiponectin or leptin. Contrarily, leptin may also enhance vascular constriction. However, in pathologic conditions these properties of PVAT seem to be
Fig. 2 Products of perivascular adipose tissue involved in regulation of (micro)vascular function. Depicted is perivascular adipose tissue in a biopsy taken from the quadriceps muscle of a type 2 diabetic patient. The black arrow indicates a microvessel. ADRF - adventitia-derived relaxing factor; Ang IIangiotensin II; Ang (1-7) angiotensin (1-7); FABP4 - fatty acid-binding protein 4 ; $\mathrm{H}_{2} \mathrm{~S}$ - hydrogen sulphate; ILinterleukin-; MCP-1-monocyte chemoattractant protein-1; MIP$1 \alpha$-macrophage inflammatory protein- $1 \alpha$; ROS - reactive oxygen species; TNF $\alpha$-tumor necrosis factor $\alpha$

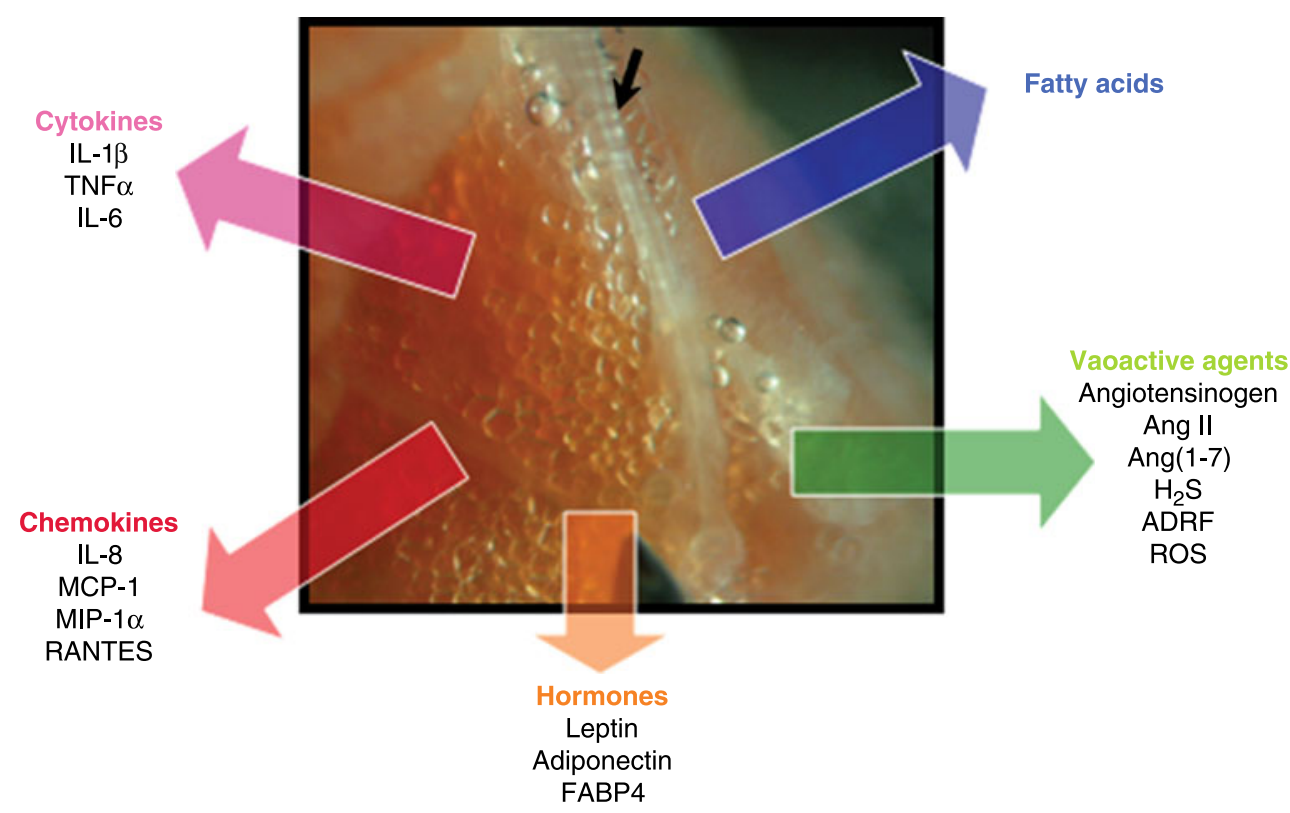


attenuated. The exact mechanisms through which PVAT modulates (micro)vascular tone remain to be investigated.

\section{Direct Effects of PVAT on Smooth Muscle Tone}

Aside from interaction with vascular endothelium, perivascular adipose tissue is also able to act directly on vascular smooth muscle to determine vascular tone and diameter via release of both vasodilator and vasoconstrictor substances.

Vasorelaxation by perivascular adipose tissue of the aorta was the first vasoactive effect reported for PVAT, leading to the proposed release of an ADRF (or perivascular adipose tissue derived relaxing factor [PVRF]) [125]. In spontaneously hypertensive rats [126] and insulinresistant fructose-fed rats [127], the relaxing effect of PVAT on mesenteric arteries was found to be impaired. At present, the nature of the ADRFs is not fully clear, although angiotensin 1-7 [115], adiponectin [25••], and hydrogen sulfide [128] have been mentioned as ADRFs. Interestingly, adiponectin receptor blockade did not inhibit the relaxing effect of PVAT in the rat mesenteric bed [129], in contrast to the PVAT effect in human adipose tissue. This indicates that ADRFs may be different between various tissues, species, or both.

PVAT is also able to enhance vasoconstrictor responses, the mediator of which is likely angiotensin II. In mesenteric arteries, PVAT was shown to enhance constriction induced by nerve stimulation, an effect mediated by angiotensin II [130].

In summary, PVAT interacts with smooth muscle tone via direct as well as indirect mechanisms, which are likely tissue specific. The net effect of PVAT can either be vasoconstrictor or vasodilator, and it is modulated by obesity and hypertension.

\section{PVAT and Insulin Sensitivity}

As mentioned above, vascular function, and especially microvascular blood volume in muscle, is related to insulin sensitivity. Because obesity is associated with insulin resistance, reduction of microvascular blood volume, and altered properties of PVAT, we have proposed that PVAT causes microvascular dysfunction and insulin resistance in obesity $[23,131]$. Although there are at present no studies that prospectively link PVAT to diabetes, a number of studies provide indirect evidence for this hypothesis. First, accumulation of ectopic adipose tissue, especially within muscles, strongly relates to local insulin sensitivity. The amount of PVAT surrounding the brachial artery [27.0] and adipose tissue between muscles (intermuscular adipose tissue [IMAT]) [132] are inversely related to insulin sensitivity. Even though IMAT accounts for only 3\% of total thigh adipose tissue, it has the strongest correlation with insulin sensitivity in obese subjects and subjects with type 2 diabetes mellitus [133]. Second, aside from intermuscular adipose tissue and PVAT around the femoral artery, we have found accumulation of PVAT around the arterioles that regulate muscle perfusion [131]. By regulating endotheliumdependent vasodilatation, insulin-mediated vasoreactivity, and muscle perfusion, PVAT may control muscle glucose uptake and, hence, determine risk of future type 2 diabetes.

Taken together, these data support the hypothesis that PVAT is one of the causes of insulin resistance. The strongest data for or against this hypothesis will likely come from PVAT-specific transgenic mouse models, but at present such models do not exist.

\section{Conclusions}

There is solid evidence for an important role for the microcirculation as a possible link between the cardiometabolic risk factors insulin resistance and hypertension, conditions that may further develop into diabetes with subsequent cardiovascular disease. Obesity is an important risk factor for insulin resistance and hypertension, and it is associated with several impairments in the microcirculation, including impaired endothelial function and rarefaction. Recent studies have shown that PVAT relates to endothelium-dependent vasodilatation and inflammation by secreting a variety of substances that affect vascular tone and infiltration of inflammatory cells (Fig. 2). However, the mechanisms controlling the quantity of PVAT and its secretion of adipokines remain to be determined. Because PVAT is located within insulin target tissues, controls (micro)vascular function, and is associated with insulin resistance, it may well contribute to the pathogenesis of type 2 diabetes and cardiovascular disease.

Disclosure No conflicts of interest relevant to this article were reported.

Open Access This article is distributed under the terms of the Creative Commons Attribution Noncommercial License which permits any noncommercial use, distribution, and reproduction in any medium, provided the original author(s) and source are credited.

\section{References}

Papers of particular interest, published recently, have been highlighted as:

- Of importance

•• Of major importance

1. Han TS, Feskens EJ, Lean ME, Seidell JC. Associations of body composition with type 2 diabetes mellitus. Diab Med. 1998;15: 129-35. 
2. Reaven GM, Banting lecture. Role of insulin resistance in human disease. Diabetes. 1988;1988(37):1595-607.

3. Flegal KM, Carroll MD, Ogden CL, Johnson CL. Prevalence and trends in obesity among US adults, 1999-2000. JAMA. 2002;288:1723-7.

4. Clark MG, Wallis MG, Barrett EJ, et al. Blood flow and muscle metabolism: a focus on insulin action. Am J Physiol Endocrinol Metab. 2003;284:E241-58.

5. Serne EH, Gans RO, ter Maaten JC, et al. Capillary recruitment is impaired in essential hypertension and relates to insulin's metabolic and vascular actions. Cardiovasc Res. 2001;49:161-8.

6. Serne EH, Stehouwer CD, ter Maaten JC, et al. Microvascular function relates to insulin sensitivity and blood pressure in normal subjects. Circulation. 1999;99:896-902.

7. Wallis $\mathrm{MG}$, Wheatley $\mathrm{CM}$, Rattigan $\mathrm{S}$, et al. Insulin-mediated hemodynamic changes are impaired in muscle of Zucker obese rats. Diabetes. 2002;51:3492-8.

8. Antonios TF, Singer DR, Markandu ND, Mortimer PS, MacGregor GA. Rarefaction of skin capillaries in borderline essential hypertension suggests an early structural abnormality. Hypertension. 1999;34:655-8.

9. Noon JP, Walker BR, Webb DJ, et al. Impaired microvascular dilatation and capillary rarefaction in young adults with a predisposition to high blood pressure. J Clin Invest. 1997;99: 1873-9.

10. Agapitov AV, Correia ML, Sinkey CA, Dopp JM, Haynes WG. Impaired skeletal muscle and skin microcirculatory function in human obesity. J Hypertens. 2002;20:1401-5.

11. de Jongh RT, Serne EH, Ijzerman RG, de Vries G, Stehouwer $\mathrm{CD}$. Impaired microvascular function in obesity: implications for obesity-associated microangiopathy, hypertension, and insulin resistance. Circulation. 2004;109:2529-35.

12. - Jonk AM, Houben AJ, Schaper NC, et al. Meal-related increases in microvascular vasomotion are impaired in obese individuals: a potential mechanism in the pathogenesis of obesity-related insulin resistance. Diabetes Care. 2011;34:S342-8. This article reviews the literature on the role of impairment of insulin-stimulated microvascular perfusion in the pathogenesis of obesity-related hypertension and insulin resistance. In addition, it adds original data on meal-induced stimulation of microvascular vasomotion, which is impaired in obese subjects.

13. Levy BI, Ambrosio G, Pries AR, Struijker-Boudier HA. Microcirculation in hypertension: a new target for treatment? Circulation. 2001;104:735-40.

14. Johnson PC. Active and passive determinants of capillary density: a historical perspective. Int $\mathrm{J}$ Microcirc Clin Exp. 1995; 15:218-22.

15. Verdant C, De Backer D. How monitoring of the microcirculation may help us at the bedside. Curr Opin Crit Care. 2005;11:240-4.

16. Feletou M, Kohler R, Vanhoutte PM. Endothelium-derived vasoactive factors and hypertension: possible roles in pathogenesis and as treatment targets. Curr Hypertens Rep. 2010;12:267-75.

17. Hu Y, Zhang Z, Torsney E, et al. Abundant progenitor cells in the adventitia contribute to atherosclerosis of vein grafts in ApoE-deficient mice. J Clin Invest. 2004;113:1258-65.

18. Thureson-Klein A, Stijarne L. Ultrastructural features of mast cells in human omental veins. Blood Vessels. 1979;16:311-9.

19. Takaoka M, Suzuki H, Shioda S, et al. Endovascular injury induces rapid phenotypic changes in perivascular adipose tissue. Arterioscler Thromb Vasc Biol. 2010;30:1576-82.

20. Mazurek T, Zhang L, Zalewski A, et al. Human epicardial adipose tissue is a source of inflammatory mediators. Circulation. 2003; $108: 2460-6$.

21. Police SB, Thatcher SE, Charnigo R, Daugherty A, Cassis LA. Obesity promotes inflammation in periaortic adipose tissue and angiotensin II-induced abdominal aortic aneurysm formation. Arterioscler Thromb Vasc Biol. 2009;29:1458-64.

22. Verlohren S, Dubrovska G, Tsang SY, et al. Visceral periadventitial adipose tissue regulates arterial tone of mesenteric arteries. Hypertension. 2004;44:271-6.

23. Yudkin JS, Eringa E, Stehouwer CD. "Vasocrine" signalling from perivascular fat: a mechanism linking insulin resistance to vascular disease. Lancet. 2005;365:1817-20.

24. Montani JP, Carroll JF, Dwyer TM, et al. Ectopic fat storage in heart, blood vessels and kidneys in the pathogenesis of cardiovascular diseases. Int $\mathrm{J}$ Obes Relat Metab Disord. 2004;28 Suppl 4:S58-65.

25. •- Greenstein AS, Khavandi K, Withers SB, et al. Local Inflammation and Hypoxia Abolish the Protective Anticontractile Properties of Perivascular Fat in Obese Patients. Circulation 2009, 119:1661-70. This study showed for the first time that adiponectin from human PVAT surrounding resistance arteries increases NO bioavailability. This vasodilatory effect of adiponectin was blunted in subjects with metabolic syndrome.

26. Iacobellis G, Ribaudo MC, Assael F, et al. Echocardiographic epicardial adipose tissue is related to anthropometric and clinical parameters of metabolic syndrome: a new indicator of cardiovascular risk. J Clin Endocrinol Metab. 2003;88:5163-8.

27. •• Rittig K, Staib K, Machann J, et al. Perivascular fatty tissue at the brachial artery is linked to insulin resistance but not to local endothelial dysfunction. Diabetologia 2008, 51:2093-9. This study showed that the amount of PVAT around the brachial artery correlates with whole body insulin sensitivity. Furthermore, it was shown that this correlation was independent of the amount of visceral adipose tissue.

28. Lu C, Su LY, Lee RM, Gao YJ. Mechanisms for perivascular adipose tissue-mediated potentiation of vascular contraction to perivascular neuronal stimulation: the role of adipocyte-derived angiotensin II. Eur J Pharmacol. 2010;634:107-12.

29. • Chatterjee TK, Stoll LL, Denning GM, et al. Proinflammatory Phenotype of Perivascular Adipocytes: Influence of High-Fat Feeding. Circ Res 2009, 104:541-9. This study showed that PVAT exhibits an increased proinflammatory response after 2 weeks of a high-fat diet. This response was stronger in PVAT than in other adipose tissue depots. Therefore, PVAT can be considered a distinctive depot of adipose tissue.

30. Tilg H, Moschen AR. Adipocytokines: mediators linking adipose tissue, inflammation and immunity. Nat Rev Immunol. 2006;6:772-83.

31. Levy BI, Schiffrin EL, Mourad JJ, et al. Impaired tissue perfusion: a pathology common to hypertension, obesity, and diabetes mellitus. Circulation. 2008;118:968-76.

32. Antonios TF, Rattray FM, Singer DR, et al. Rarefaction of skin capillaries in normotensive offspring of individuals with essential hypertension. Heart. 2003;89:175-8.

33. Caballero AE. Endothelial dysfunction, inflammation, and insulin resistance: a focus on subjects at risk for type 2 diabetes. Curr Diab Rep. 2004;4:237-46.

34. Jorneskog G, Kalani M, Kuhl J, et al. Early microvascular dysfunction in healthy normal-weight males with heredity for type 2 diabetes. Diabetes Care. 2005;28:1495-7.

35. Kim JA, Montagnani M, Koh KK, Quon MJ. Reciprocal relationships between insulin resistance and endothelial dysfunction: molecular and pathophysiological mechanisms. Circulation. 2006;113:1888-904.

36. - Kubota T, Kubota N, Kumagai $\mathrm{H}$, et al. Impaired Insulin Signaling in Endothelial Cells Reduces Insulin-Induced Glucose Uptake by Skeletal Muscle. Cell Metabolism 2011, 13:294-307. This study provides extensive data on the pivotal role of insulin signaling in endothelial cells in the regulation of glucose uptake by skeletal muscle. 
37. Baron AD. Cardiovascular actions of insulin in humans. Implications for insulin sensitivity and vascular tone. Baillieres Clin Endocrinol Metab. 1993;7:961-87.

38. Baron AD. Hemodynamic actions of insulin. Am J Physiol. 1994;267:E187-202.

39. de Haan CH, van Dielen FM, Houben AJ, et al. Peripheral blood flow and noradrenaline responsiveness: the effect of physiological hyperinsulinemia. Cardiovasc Res. 1997;34:192-8.

40. Clark MG. Impaired microvascular perfusion: a consequence of vascular dysfunction and a potential cause of insulin resistance in muscle. Am J Physiol Endocrinol Metab. 2008;295:E732-50.

41. Yki-Jarvinen $\mathrm{H}$, Utriainen $\mathrm{T}$. Insulin-induced vasodilatation: physiology or pharmacology? Diabetologia. 1998;41:369-79.

42. Zhang L, Vincent MA, Richards SM, et al. Insulin sensitivity of muscle capillary recruitment in vivo. Diabetes. 2004;53:447-53.

43. Clark MG, Rattigan S, Clerk LH, et al. Nutritive and nonnutritive blood flow: rest and exercise. Acta Physiol Scand. 2000;168:519-30.

44. Zhang L, Newman JM, Richards SM, Rattigan S, Clark MG. Microvascular flow routes in muscle controlled by vasoconstrictors. Microvasc Res. 2005;70:7-16.

45. Clark AD, Barrett EJ, Rattigan S, Wallis MG, Clark MG. Insulin stimulates laser Doppler signal by rat muscle in vivo, consistent with nutritive flow recruitment. Clin Sci (Lond). 2001;100:283-90.

46. Rattigan S, Clark MG, Barrett EJ. Hemodynamic actions of insulin in rat skeletal muscle: evidence for capillary recruitment. Diabetes. 1997;46:1381-8.

47. Vincent MA, Barrett EJ, Lindner JR, Clark MG, Rattigan S. Inhibiting NOS blocks microvascular recruitment and blunts muscle glucose uptake in response to insulin. Am J Physiol Endocrinol Metab. 2003;285:E123-9.

48. Baron AD, Tarshoby M, Hook G, et al. Interaction between insulin sensitivity and muscle perfusion on glucose uptake in human skeletal muscle: evidence for capillary recruitment. Diabetes. 2000;49:768-74.

49. Bonadonna RC, Saccomani MP, Del Prato S, et al. Role of tissue-specific blood flow and tissue recruitment in insulinmediated glucose uptake of human skeletal muscle. Circulation. 1998;98:234-41.

50. Vincent MA, Montagnani M, Quon MJ. Molecular and physiologic actions of insulin related to production of nitric oxide in vascular endothelium. Curr Diab Rep. 2003;3:279-88.

51. Vincent MA, Clerk LH, Lindner JR, et al. Microvascular recruitment is an early insulin effect that regulates skeletal muscle glucose uptake in vivo. Diabetes. 2004;53:1418-23.

52. Newman JM, Dwyer RM, St-Pierre P, et al. Decreased microvascular vasomotion and myogenic response in rat skeletal muscle in association with acute insulin resistance. J Physiol. 2009;587:2579-88.

53. Potenza MA, Marasciulo FL, Chieppa DM, et al. Insulin resistance in spontaneously hypertensive rats is associated with endothelial dysfunction characterized by imbalance between NO and ET-1 production. Am J Physiol Heart Circ Physiol. 2005;289:H813-22.

54. Eringa EC, Stehouwer CD, van Nieuw Amerongen GP, et al. Vasoconstrictor effects of insulin in skeletal muscle arterioles are mediated by ERK1/2 activation in endothelium. Am J Physiol Heart Circ Physiol. 2004;287:H2043-8.

55. Jonk AM, Houben AJ, de Jongh RT, et al. Microvascular dysfunction in obesity: a potential mechanism in the pathogenesis of obesity associated insulin resistance and hypertension. Physiology. 2007;22:252-60.

56. Arcaro G, Zamboni M, Rossi L, et al. Body fat distribution predicts the degree of endothelial dysfunction in uncomplicated obesity. Int J Obes Relat Metab Disord. 1999;23:936-42.
57. De Filippis E, Cusi K, Ocampo G, et al. Exercise-induced improvement in vasodilatory function accompanies increased insulin sensitivity in obesity and type 2 diabetes mellitus. J Clin Endocrinol Metab. 2006;91:4903-10.

58. Mavri A, Poredos P, Suran D, Gaborit B, Juhan-Vague I. Effect of diet-induced weight loss on endothelial dysfunction: early improvement after the first week of dieting. Heart Vessels. 2011;26:31-8.

59. Steinberg HO, Chaker H, Leaming R, et al. Obesity/insulin resistance is associated with endothelial dysfunction. Implications for the syndrome of insulin resistance. J Clin Invest. 1996;97: 2601-10.

60. Van Guilder GP, Hoetzer GL, Dengel DR, Stauffer BL, DeSouza CA. Impaired endothelium-dependent vasodilation in normotensive and normoglycemic obese adult humans. J Cardiovasc Pharmacol. 2006;47:310-3.

61. Van Guilder GP, Stauffer BL, Greiner JJ, Desouza CA. Impaired endothelium-dependent vasodilation in overweight and obese adult humans is not limited to muscarinic receptor agonists. Am J Physiol Heart Circ Physiol. 2008;294:H168592.

62. Czernichow S, Greenfield JR, Galan P, et al. Microvascular dysfunction in healthy insulin-sensitive overweight individuals. J Hypertens. 2010;28:325-32.

63. Ziccardi P, Nappo F, Giugliano G, et al. Reduction of inflammatory cytokine concentrations and improvement of endothelial functions in obese women after weight loss over one year. Circulation. 2002;105:804-9.

64. Piatti PM, Monti LD, Conti M, et al. Hypertriglyceridemia and hyperinsulinemia are potent inducers of endothelin-1 release in humans. Diabetes. 1996;45:316-21.

65. Cusi K, Maezono K, Osman A, et al. Insulin resistance differentially affects the PI 3-kinase- and MAP kinase-mediated signaling in human muscle. J Clin Invest. 2000;105:311-20.

66. Eringa EC, Stehouwer CD, Roos MH, Westerhof N, Sipkema P. Selective resistance to vasoactive effects of insulin in muscle resistance arteries of obese Zucker (fa/fa) rats. Am J Physiol Endocrinol Metab. 2007;293:E1134-9.

67. Jiang ZY, Lin YW, Clemont A, et al. Characterization of selective resistance to insulin signaling in the vasculature of obese Zucker (fa/fa) rats. J Clin Invest. 1999;104:447-57.

68. de Jongh RT, Serne EH, Ijzerman RG, de Vries G, Stehouwer CD. Free fatty acid levels modulate microvascular function: relevance for obesity-associated insulin resistance, hypertension, and microangiopathy. Diabetes. 2004;53:2873-82.

69. Clerk LH, Vincent MA, Jahn LA, et al. Obesity blunts insulinmediated microvascular recruitment in human forearm muscle. Diabetes. 2006;55:1436-42.

70. • Keske MA, Clerk LH, Price WJ, Jahn LA, Barrett EJ. Obesity blunts microvascular recruitment in human forearm muscle after a mixed meal. Diabetes Care 2009, 32:1672-1677. This study showed that a mixed meal induces a recruitment of muscle microvasculature and muscle blood flow in lean subjects. This effect was blunted in obese subjects.

71. Laakso M, Edelman SV, Brechtel G, Baron AD. Decreased effect of insulin to stimulate skeletal muscle blood flow in obese man. A novel mechanism for insulin resistance. J Clin Invest. 1990;85:1844-52.

72. Tack CJ, Ong MK, Lutterman JA, Smits P. Insulin-induced vasodilatation and endothelial function in obesity/insulin resistance. Effects of troglitazone. Diabetologia. 1998;41:569-76.

73. Eringa EC, Stehouwer CD, Merlijn T, Westerhof N, Sipkema P. Physiological concentrations of insulin induce endothelin-mediated vasoconstriction during inhibition of NOS or PI3-kinase in skeletal muscle arterioles. Cardiovasc Res. 2002;56:464-71.

74. Mather KJ, Lteif A, Steinberg HO, Baron AD. Interactions between endothelin and nitric oxide in the regulation of 
vascular tone in obesity and diabetes. Diabetes. 2004;53: 2060-6.

75. Mather KJ, Mirzamohammadi B, Lteif A, Steinberg HO, Baron AD. Endothelin contributes to basal vascular tone and endothelial dysfunction in human obesity and type 2 diabetes. Diabetes. 2002;51:3517-23.

76. Versari D, Daghini E, Virdis A, Ghiadoni L, Taddei S. Endothelium-dependent contractions and endothelial dysfunction in human hypertension. Br J Pharmacol. 2009;157:527-36.

77. Houben AJ, Canoy MC, Paling HA, Derhaag PJ, de Leeuw PW. Quantitative analysis of retinal vascular changes in essential and renovascular hypertension. J Hypertens. 1995;13:1729-33.

78. Debbabi H, Uzan L, Mourad JJ, et al. Increased skin capillary density in treated essential hypertensive patients. Am J Hypertens. 2006; 19:477-83.

79. Serne EH, Gans RO, ter Maaten JC, et al. Impaired skin capillary recruitment in essential hypertension is caused by both functional and structural capillary rarefaction. Hypertension. 2001;38:238-42.

80. Panza JA, Quyyumi AA, Brush Jr JE, Epstein SE. Abnormal endothelium-dependent vascular relaxation in patients with essential hypertension. N Engl J Med. 1990;323:22-7.

81. Potenza MA, Marasciulo FL, Chieppa DM, et al. Insulin resistance in spontaneously hypertensive rats is associated with endothelial dysfunction characterized by imbalance between NO and ET-1 production. Am J Physiol Heart Circ Physiol. 2005;289:H813-22.

82. Li R, Zhang H, Wang W, et al. Vascular insulin resistance in prehypertensive rats: role of PI3-kinase/Akt/eNOS signaling. Eur J Pharmacol. 2010;628:140-7.

83. Zhou MS, Schulman IH, Raij L. Role of angiotensin II and oxidative stress in vascular insulin resistance linked to hypertension. Am J Physiol Heart Circ Physiol. 2009;296:H833-9.

84. Gaboury CL, Simonson DC, Seely EW, Hollenberg NK, Williams $\mathrm{GH}$. Relation of pressor responsiveness to angiotensin II and insulin resistance in hypertension. J Clin Invest. 1994;94:2295-300.

85. Struijker Boudier HA, le Noble JL, Messing MW, et al. The microcirculation and hypertension. J Hypertens Suppl. 1992;10: S147-56.

86. Ungvari Z, Csiszar A, Kaminski PM, Wolin MS, Koller A. Chronic high pressure-induced arterial oxidative stress: involvement of protein kinase $\mathrm{C}$-dependent $\mathrm{NAD}(\mathrm{P}) \mathrm{H}$ oxidase and local renin-angiotensin system. Am J Pathol. 2004;165:219-26.

87. Eftekhari A, Mathiassen ON, Buus NH, et al. Disproportionally impaired microvascular structure in essential hypertension. J Hypertens. 2011;29:896-905.

88. Kobayashi N, DeLano FA, Schmid-Schonbein GW. Oxidative stress promotes endothelial cell apoptosis and loss of microvessels in the spontaneously hypertensive rats. Arterioscler Thromb Vasc Biol. 2005;25:2114-21.

89. Nabha L, Garbern JC, Buller CL, Charpie JR. Vascular oxidative stress precedes high blood pressure in spontaneously hypertensive rats. Clin Exp Hypertens. 2005;27:71-82.

90. Jonk AM. Microvascular actions of insulin: studies on the interaction with angiotensin II and on the postprandial state. Amsterdam: GVO drukkers \& vormgevers B.V. | Ponsen \& Looijen; 2011.

91. Giugliano D, Marfella R, Coppola L, et al. Vascular effects of acute hyperglycemia in humans are reversed by L-arginine. Evidence for reduced availability of nitric oxide during hyperglycemia. Circulation. 1997;95:1783-90.

92. Watanabe K, Oba K, Suzuki T, et al. Oral glucose loading attenuates endothelial function in normal individual. Eur J Clin Invest. 2011;41:465-73.

93. de Jongh RT, IJzerman RG, Serne EH, et al. Visceral and truncal subcutaneous adipose tissue are associated with impaired capillary recruitment in healthy individuals. J Clin Endocrinol Metab. 2006;91:5100-6.

94. Hotamisligil GS, Arner P, Caro JF, Atkinson RL, Spiegelman BM. Increased adipose tissue expression of tumor necrosis factor-alpha in human obesity and insulin resistance. J Clin Invest. 1995;95:2409-15.

95. Singhal A. Endothelial dysfunction: role in obesityrelated disorders and the early origins of CVD. Proc Nutr Soc. 2005;64:15-22.

96. Williams IL, Wheatcroft SB, Shah AM, Kearney MT. Obesity, atherosclerosis and the vascular endothelium: mechanisms of reduced nitric oxide bioavailability in obese humans. Int J Obes Relat Metab Disord. 2002;26:754-64.

97. Yudkin JS, Stehouwer CD, Emeis JJ, Coppack SW. C-reactive protein in healthy subjects: associations with obesity, insulin resistance, and endothelial dysfunction: a potential role for cytokines originating from adipose tissue? Arterioscler Thromb Vasc Biol. 1999;19:972-8.

98. Arita Y, Kihara S, Ouchi N, et al. Paradoxical decrease of an adipose-specific protein, adiponectin, in obesity. Biochem Biophys Res Commun. 1999;257:79-83.

99. Koenig W, Khuseyinova N, Baumert J, Meisinger C, Lowel H. Serum concentrations of adiponectin and risk of type 2 diabetes mellitus and coronary heart disease in apparently healthy middle-aged men: results from the 18-year follow-up of a large cohort from southern Germany. J Am Coll Cardiol. 2006;48:1369-77.

100. Duncan BB, Schmidt MI, Pankow JS, et al. Adiponectin and the development of type 2 diabetes: the atherosclerosis risk in communities study. Diabetes. 2004;53:2473-8.

101. Withers SB, Gabiti-Rosei C, Livingstone DM, et al. Macrophage activation is responsible for loss of anticontractile function in inflamed perivascular fat. Arterioscler Thromb Vasc Biol. 2011;31:908-13.

102. Luo N, Liu J, Chung BH, et al. Macrophage adiponectin expression improves insulin sensitivity and protects against inflammation and atherosclerosis. Diabetes. 2010;59:791-9.

103. Date H, Imamura T, Ideguchi T, et al. Adiponectin produced in coronary circulation regulates coronary flow reserve in nondiabetic patients with angiographically normal coronary arteries. Clin Cardiol. 2006;29:211-4.

104. Iacobellis G, Pistilli D, Gucciardo M, et al. Adiponectin expression in human epicardial adipose tissue in vivo is lower in patients with coronary artery disease. Cytokine. 2005;29:251-5.

105. Fesus G, Dubrovska G, Gorzelniak K, et al. Adiponectin is a novel humoral vasodilator. Cardiovasc Res. 2007;75:719-27.

106. Zhang Y, Proenca R, Maffei M, et al. Positional cloning of the mouse obese gene and its human homologue. Nature. 1994;372:425-32.

107. Vecchione C, Aretini A, Maffei A, et al. Cooperation between insulin and leptin in the modulation of vascular tone. Hypertension. 2003;42:166-70.

108. Montague CT, Farooqi IS, Whitehead JP, et al. Congenital leptin deficiency is associated with severe early-onset obesity in humans. Nature. 1997;387:903-8.

109. Chen K, Li F, Li J, et al. Induction of leptin resistance through direct interaction of C-reactive protein with leptin. Nat Med. 2006;12:425-32.

110. Payne GA, Borbouse L, Kumar S, et al. Epicardial perivascular adipose-derived leptin exacerbates coronary endothelial dysfunction in metabolic syndrome via a protein kinase C-beta pathway. Arterioscler Thromb Vasc Biol. 2010;30:1711-7.

111. Henrichot E, Juge-Aubry CE, Pernin A, et al. Production of chemokines by perivascular adipose tissue: a role in the pathogenesis of atherosclerosis? Arterioscler Thromb Vasc Biol. 2005;25:2594-9. 
112. Takaoka M, Suzuki H, Shioda S, et al. Endovascular injury induces rapid phenotypic changes in perivascular adipose tissue. Arterioscler Thromb Vasc Biol. 2010;30:1576-82.

113. Guzik TJ, Mussa S, Gastaldi D, et al. Mechanisms of increased vascular superoxide production in human diabetes mellitus: role of $\mathrm{NAD}(\mathrm{P}) \mathrm{H}$ oxidase and endothelial nitric oxide synthase. Circulation. 2002;105:1656-62.

114. Dubrovska G, Verlohren S, Luft FC, Gollasch M. Mechanisms of ADRF release from rat aortic adventitial adipose tissue. Am J Physiol Heart Circ Physiol. 2004;286:H1107-13.

115. Lee RM, Lu C, Su LY, Gao YJ. Endothelium-dependent relaxation factor released by perivascular adipose tissue. J Hypertens. 2009;27:782-90.

116. Galvez-Prieto B, Bolbrinker J, Stucchi P, et al. Comparative expression analysis of the renin-angiotensin system components between white and brown perivascular adipose tissue. J Endocrinol. 2008;197:55-64.

117. Furuhashi M, Ura N, Higashiura K, et al. Blockade of the reninangiotensin system increases adiponectin concentrations in patients with essential hypertension. Hypertension. 2003;42:76-81.

118. Lee MH, Song HK, Ko GJ, et al. Angiotensin receptor blockers improve insulin resistance in type 2 diabetic rats by modulating adipose tissue. Kidney Int. 2008;74:890-900.

119. Jonk AM, Houben AJ, Schaper NC, et al. Angiotensin II enhances insulin-stimulated whole-body glucose disposal but impairs insulin-induced capillary recruitment in healthy volunteers. J Clin Endocrinol Metab. 2010;95:3901-8.

120. Jonk AM, Houben AJ, Schaper NC, et al. Acute angiotensin II receptor blockade improves insulin-induced microvascular function in hypertensive individuals. Microvasc Res. 2011;82:77-83.

121. Marchesi C, Ebrahimian T, Angulo O, Paradis P, Schiffrin EL. Endothelial nitric oxide synthase uncoupling and perivascular adipose oxidative stress and inflammation contribute to vascular dysfunction in a rodent model of metabolic syndrome. Hypertension. 2009;54:1384-92.

122. Guzik TJ, Hoch NE, Brown KA, et al. Role of the T cell in the genesis of angiotensin II-induced hypertension and vascular dysfunction. J Exp Med. 2007;204:2449-60.
123. Bakker W, Eringa EC, Sipkema P, van Hinsberg VW. Endothelial dysfunction and diabetes: roles of hyperglycemia, impaired insulin signaling and obesity. Cell Tissue Res. 2009;335:165-89.

124. Chen B, Lam KS, Wang Y, et al. Hypoxia dysregulates the production of adiponectin and plasminogen activator inhibitor-1 independent of reactive oxygen species in adipocytes. Biochem Biophys Res Commun. 2006;341:549-56.

125. Gao YJ, Lu C, Su LY, Sharma AM, Lee RM. Modulation of vascular function by perivascular adipose tissue: the role of endothelium and hydrogen peroxide. Br J Pharmacol. 2007;151: 323-31.

126. Lee RM, Ding L, Lu C, Su LY, Gao YJ. Alteration of perivascular adipose tissue function in angiotensin II-induced hypertension. Can J Physiol Pharmacol. 2009;87:944-53.

127. Rebolledo A, Rebolledo OR, Marra CA, et al. Early alterations in vascular contractility associated to changes in fatty acid composition and oxidative stress markers in perivascular adipose tissue. Cardiovasc Diabetol. 2010;9:65.

128. Fang L, Zhao J, Chen Y, et al. Hydrogen sulfide derived from periadventitial adipose tissue is a vasodilator. J Hypertens. 2009;27:2174-85.

129. Fesus G, Dubrovska G, Gorzelniak K, et al. Adiponectin is a novel humoral vasodilator. Cardiovasc Res. 2007;75:719-27.

130. Lu C, Su LY, Lee RM, Gao YJ. Mechanisms for perivascular adipose tissue-mediated potentiation of vascular contraction to perivascular neuronal stimulation: the role of adipocyte-derived angiotensin II. Eur J Pharmacol. 2010;634:107-12.

131. Eringa EC, Bakker W, Smulders YM, et al. Regulation of vascular function and insulin sensitivity by adipose tissue: focus on perivascular adipose tissue. Microcirculation. 2007;14:389402.

132. Boettcher M, Machann J, Stefan N, et al. Intermuscular adipose tissue (IMAT): association with other adipose tissue compartments and insulin sensitivity. J Magn Reson Imaging. 2009;29: 1340-5.

133. Goodpaster BH, Thaete FL, Kelley DE. Thigh adipose tissue distribution is associated with insulin resistance in obesity and in type 2 diabetes mellitus. Am J Clin Nutr. 2000;71:885-92. 